ISSN: 2252-7893, Vol 2, No 12013 (hal 66-75)

http://jurnal.fkip.uns.ac.id/index.php/sains

\title{
PEMBELAJARAN FISIKA MENGGUNAKAN TEAMS GAMES TOURNAMENT MELALUI TEKA TEKI SILANG DANKARTU DITINJAU DARI KEMAMPUAN VERBAL DAN GAYA BELAJAR SISWA
}

\author{
Wahdah Rochmawati ${ }^{1}$, Widha Sunarno ${ }^{2}$, Suparmi $^{3}$ \\ ${ }^{1}$ Mahasiswa Program Studi Pendidikan Sains Program Pascasarjana Universitas Sebelas Maret \\ wahdah_rochmawati@smubatik1-slo.sch.id \\ ${ }^{2}$ Dosen Program Studi Pendidikan Sains Program Pascasarjana Universitas Sebelas Maret \\ widhasunarno@gmail.com \\ ${ }^{3}$ Dosen Program Studi Pendidikan Sains Program Pascasarjana Universitas Sebelas Maret \\ suparmiuns@gmail.com
}

\begin{abstract}
ABSTRAK
Tujuan penelitian ini adalah untuk mengetahui pengaruh pembelajaran menggunakan TGT melalui teka teki silang dan kartu, kemampuan verbal dan gaya belajar terhadap prestasi belajar fisika dan interaksinya. Penelitian ini menggunakan metode eksperimen. Populasinya terdiri dari siswa kelas XII SMAN Batik 1 Surakarta tahun pelajaran 2011/2012. Sampel yang diambil adalah 2 kelas yaitu Kelas XII IPA 1 dan XII IPA 2 dengan menggunakan teknik cluster random sampling. Teknik pengumpulan data kemampuan verbal dan prestasi kognitif digunakan metode tes. Untuk data gaya belajar dan prestasi afektif digunakan metode angket. Teknik analisis data menggunakan analisis variansi tiga jalan desain faktorial $2 \times 2 \times 2$ dengan sel tak sama. Berdasarkan hasil penelitian dapat disimpulkan: 1) terdapat pengaruh pembelajaran menggunakan TGT melalui teka teki silang dan kartu terhadap prestasi kognitif namun tidak terdapat pengaruh pembelajaran menggunakan TGT melalui teka teki silang dan kartu terhadap prestasi afektif ; 2) terdapat pengaruh kemampuan verbal tinggi dan rendah terhadap prestasi kognitif maupun afektif; 3) tidak terdapat pengaruh gaya belajar kinestetik dan visual terhadap prestasi kognitif maupun afektif; 4) tidak terdapat interaksi pembelajaran menggunakan TGT melalui teka teki silang dan kartu dengan kemampuan verbal terhadap prestasi kognitif maupun afektif; 5) tidak terdapat interaksi pembelajaran menggunakan TGT melalui teka teki silang dan kartu dengan gaya belajar terhadap prestasi kognitif maupun afektif; 6) tidak terdapat interaksi kemampuan verbal dengan gaya belajar terhadap prestasi kognitif maupun afektif; 7) tidak terdapat interaksi pembelajaran menggunakan TGT melalui teka teki silang dan kartu, kemampuan verbal, gaya belajar siswa terhadap prestasi kognitif maupun afektif.
\end{abstract}

Kata kunci : teams games tournament, teka teki silang, kartu, kemampuan verbal, gaya belajar

\section{Pendahuluan}

Seiring dengan pesatnya perkembangan ilmu pengetahuan dan teknologi, setiap negara dituntut untuk menciptakan sumber daya manusia yang berkualitas, yaitu manusia yang mempunyai kesiapan mental dan mampu berpartisipasi mengembangkan ilmu pengetahuan dan teknologi. Salah satu upaya untuk mencapai tujuan adalah dengan peningkatan kualitas pendidikan yang ada. Oleh karena itu pembangunan pendidikan diarahkan pada peningkatan proses pembelajaran dan sarana prasarana yang diperlukan. 


\section{JURNAL INKUIRI}

ISSN: 2252-7893, Vol 2, No 12013 (hal 66-75)

http://jurnal.fkip.uns.ac.id/index.php/sains

Kurikulum Berbasis Kompetensi (KBK) dikembangkan untuk mengatasi masalah yang terjadi di dunia pendidikan Indonesia, yaitu lemahnya proses belajar dan pelaksanaan pembelajaran yang masih didominasi oleh guru

(teacher centred). Kurikulum Tingkat Satuan Pendidikan (KTSP) adalah KBK yang dikembangkan yang pelaksanaannya disesuaikan oleh sekolah masing-masing. Guru sebagai fasilitator, bertugas menyiapkan perangkat pembelajaran. Pembelajaran dengan KTSP menuntut guru untuk terlibat aktif dan menyiapkan pembelajaran agar siswa terlibat aktif. Kurikulum ini menuntut adanya partisipasi aktif dari seluruh siswa dalam pembelajarannya. Jadi kegiatan belajar berpusat pada siswa (student centred), guru sebagai motivator dan fasilitator di dalamnya agar suasana kelas terasa aktif dan menyenangkan bagi siswa. Terbitnya Peraturan Menteri Pendidikan Nasional No. 41 Tahun 2007 tentang standar proses menjadikan guru harus mampu menggunakan model pembelajaran yang tepat bagi ketercapaian pelaksanaan pembelajaran di kelas dan ketercapaian kompetensi lulusan. Dalam KTSP guru lebih leluasa merancang, melaksanakan dan pengawasan serta penilaian pembelajaran untuk setiap mata pelajaran sesuai dengan satuan pendidikan, karakteristik sekolah maupun karakteristik siswa.

Rancangan pelaksanaan pembelajaran yang baik dan ketepatan dalam pemilihan metode ataupun model pembelajaran sangat diperlukan agar hasil yang diperoleh dapat optimal. Kenyataan yang tidak dapat dipungkiri bahwa banyak siswa mengatakan mata pelajaran fisika itu sulit, banyak hitungan matematisnya, banyak rumus, monoton, membosankan, kurang memberi tantangan dan tidak menarik, sehingga banyak siswa yang tidak menyukai fisika. Hal ini dibuktikan bahwa rata-rata hasil prestasi belajar fisika masih rendah. Faktor-faktor yang mempengaruhi prestasi belajar fisika antara lain adalah pemahaman konsep, sarana dan prasarana pendidikan, guru, siswa, model pembelajaran yang diterapkan, motivasi, kemampuan awal, cara belajar yang diinginkan siswa, aktifitas belajar dll.

Fisika sebagai salah satu bagian dari Ilmu Pengetahuan Alam yang menjelaskan gejala-gejala alam yang teramati di sekitar lingkungan hidup siswa baik pengamatan langsung maupun tidak langsung. Maka perlu pembelajaran fisika yang sesuai. Pembelajaran ini dengan pengamatan tak langsung bisa dibantu dengan media. Pendidikan IPA diarahkan untuk mencari tahu dan berbuat sehingga dapat membantu siswa untuk memperoleh pemahaman yang lebih mendalam tentang konsep dan proses sains. Ketrampilan proses ini meliputi keterampilan mengamati, mengajukan hipotesis, menggunakan alat dan bahan secara baik dan benar dengan selalu mempertimbangkan keamanan dan keselamatan kerja, mengajukan pertanyaan, menggolongkan dan menafsirkan data serta mengkomunikasikan hasil temuan secara lisan dan tertulis, menggali dan memilih informasi faktual yang relevan untuk menguji gagasan-gagasan atau memecahkan masalah sehari-hari. Namun demikian tidak semua materi fisika dapat dipelajari dengan pengamatan langsung, seperti halnya materi fisika atom, karena bendanya sangat kecil tidak dapat diamati langsung dengan panca indera dan materinya bersifat abstrak. Sehingga perlu cara lain untuk menyampaikan materi baik pada penggunaan media, metode maupun model pembelajaran. sekarang ini merupakan hasil pengembangan para peneliti pendidikan. Salah satu tujuan para peneliti pendidikan tentunya agar proses pembelajaran di kelas lebih maksimal dan tidak membosankan. Ada model yang mempunyai keunggulan dalam memecahkan masalah pembelajaran dan membawa siswa untuk lebih efektif dalam belajar. Salah satu model pembelajaran yang perlu dipertimbangkan adalah pembelajaran kooperatif (cooperative learning). Dalam 


\section{JURNAL INKUIRI}

ISSN: 2252-7893, Vol 2, No 12013 (hal 66-75)

http://jurnal.fkip.uns.ac.id/index.php/sains

pembelajaran kooperatif, para siswa akan duduk bersama dalam kelompok beranggotakan empat orang untuk menguasai materi pelajaran yang diberikan oleh guru (Slavin, 2008:8). Slavin dalam Wina Sanjaya (2008:242) mengemukakan dua alasan yaitu, "pertama beberapa hasil penelitian membuktikan bahwa penggunaan metode pembelajaran kooperatif dapat meningkatkan prestasi belajar siswa sekaligus dapat meningkatkan hubungan soaial dan kedua, dapat mengintegrasikan pengetahuan dengan pengalaman". Namun kenyataannya model pembelajaran kooperatif belum banyak diaplikasikan dalam pembelajaran.

Model pembelajaran kooperatif antara lain STAD, GI, Jigsaw, TGT. Dengan model ini siswa akan lebih mudah menemukan konsep-konsep materi fisika, menyelesaikan soal, melakukan eksperimen dan saling mendiskusikan masalah-masalah yang dihadapi siswa. Siswa yang berdiskusi akan saling tukar menukar pengalaman, pikiran serta saling mengisi kekurangan-kekurangannya.

Dalam Student Team Achiviemnet Division (STAD), para siswa dibagi dalam tim belajar yang terdiri atas empat orang yang berbeda-beda tingkat kemampuan, jenis kelamin, dan latar belakang etniknya. Guru menyampaikan pelajaran, lalu siswa bekerja dalam tim mereka untuk memastikan bahwa semua anggota tim telah menguasai pelajaran. Selanjutnya semua siswa mengerjakan kuis mengenai materi secara sendiri-sendiri, saat itu juga semua siswa tidak diperbolehkan untuk saling membantu. Skor kuis para siswa dibandingkan dengan rata-rata pencapaian mereka sebelumnya, dan kepada masingmasing tim akan diberikan poin berdasarkan tingkat kemajuan yang diraih siswa dibandingkan hasil yang dicapai sebelumnya. Poin ini kemudian dijumlahkan untuk memperoleh skor tim, dan tim yang berhasil memenuhi kriteria tertentu akan mendapatkan sertifikat atau penghargaan lainnya.

Sedangkan Group Investigation (GI), siswa dibebaskan membentuk kelompok kecil yang terdiri dua sampai enam orang anggota. Kelompok ini kemudian memilih topik-topik dari unit yang telah dipelajari oleh seluruh kelas, membagi topik-topik ini menjadi tugastugas pribadi dan melakukan kegiatan yang diperlukan untuk mempersiapkan laporan kelompok. Tiap kelompok lalu mempresentasikan atau menampilkan penemuan mereka di hadapan seluruh kelas.

Model kooperatif yang lain yaitu Jigsaw, pada model ini siswa bekerja dalam tim yang heterogen kemudian diberi tugas untuk membaca beberapa bab dan diberikan lembar ahli yang terdiri atas topik-topik yang berbeda yang harus menjadi fokus perhatian masing-masing anggota tim saat membaca. Setelah membaca, siswa dari tim yang berbeda tetapi mempunyai topik yang sama bertemu dalam kelompok ahli untuk mendiskusikan topik yang dipelajari dalam waktu tertentu. Para ahli kemudian kembali ke tim semula dan secara bergantian mengajari teman satu tim mengenai topik masing-masing. Setelah semua topik dipelajari kemudian para siswa akan menerima penilaian yang mencakup seluruh topik.

Pada penelitian ini menggunakan model yang sesuai dengan kemampuan siswa dan karakteristik materi yang disampaikan yaitu model TGT, supaya pembelajaran lebih efektif, siswa lebih senang, termotivasi dan tertarik. Model kooperatif tipe TGT (Teams Games Tournaments) bermaksud untuk: 1) mengurangi sifat egosentris dan individualistis siswa; 2) belajar dengan melakukan kerjasama dalam kelompokkelompok belajar; 3) mengembangkan ketrampilan social dan komunikasi siswa; 4) meningkatkan aktivitas belajar siswa; 5) meningkatkan motivasi belajar siswa; 6) meningkatkan keberagaman; 7) meningkatkan prestasi belajar siswa. Pelaksanaan pembelajaran kooperatif akan berhasil, apabila masing-masing siswa telah menguasai ketrampilan kooperatif yang merupakan aktivitas belajar dalam kelompok kerja. 


\section{JURNAL INKUIRI}

ISSN: 2252-7893, Vol 2, No 12013 (hal 66-75)

\section{http://jurnal.fkip.uns.ac.id/index.php/sains}

Materi Fisika Atom merupakan materi yang sangat penting, karena atom merupakan penyusun materi yang ada di alam semesta. Dengan memahami atom dapat mempelajari bagaimana satu atom dengan yang lain berinteraksi, mengetahui sifat-sifat atom, dan sebagainya sehingga dapat memanfaatkan alam semesta untuk kepentingan umat manusia. Materi Fisika Atom merupakan materi yang sulit bagi siswa. Hal ini terlihat dari persentase penguasaan materi soal fisika ujian nasional paket A 42,47 dan paket B 77,78. Sehingga perlu dilakukan variasi model pembelajaran yang dapat meningkatkan keaktifan siswa dan agar siswa tidak merasa jenuh atau bosan dalam kegiatan belajarnya.

Kegiatan belajar mengajar mata pelajaran Fisika di SMA Batik 1 surakarta khususnya materi Fisika Atom, guru masih menggunakan model konvensional yakni ceramah, walaupun menggunakan LCD ternyata hanya untuk memudahkan guru dalam penulisan di papan tulis saja. Siswa kurang dilibatkan dalam proses pembelajaran, akibatnya pencapaian nilai Fisika belum maksimal

Pencapaian prestasi belajar siswa dipengaruhi oleh dua faktor yaitu faktor internal dan faktor eksternal. Faktor internal merupakan faktor yang berasal dari diri siswa seperti kemampuan awal, sikap ilmiah, aktivitas, motivasi, kreativitas, kemampuan verbal, gaya belajar, interaksi sosial, bakat dan lain sebagainya. Namun kenyataan masih kurang perhatian guru terhadap faktorfaktor tersebut. Oleh karena itu yang terkait dengan karakteristik materi Fisika Atom perlu memperhatikan kemampuan verbal dan gaya belajar siswa.

Faktor eksternal merupakan faktor yang berasal dari luar siswa, seperti model pembelajaran, lingkungan tempat tinggal, sarana prasarana, media pembelajaran. Media pembelajaran yang dapat digunakan dalam pembelajaran Fisika Atom diantaranya Teka-Teki Silang dan Kartu. Karena materi fisika atom tidak dapat diamati secara langsung, maka membutuhkan media untuk mempermudah pemahaman siswa. Kedua faktor tersebut sangat berpengaruh dalam pencapaian tinggi dan rendahnya prestasi yang akan diraih oleh siswa dalam pembelajaran.

Berdasarkan uraian di atas maka akan dilaksanakan penelitian menerapkan pembelajaran fisika menggunakan TGT melalui teka teki silang dan kartu ditinjau dari kemampuan verbal dan gaya belajar siswa. Adapun tujuan dalam penelitian ini adalah untuk mengetahui: (1) pengaruh pembelajaran TGT melalui teka-teki silang dan kartu terhadap prestasi belajar fisika, (2) pengaruh tingkat kemampuan verbal siswa, tinggi, dan rendah terhadap prestasi belajar fisika, (3) pengaruh gaya belajar siswa, kinestetik dan visual terhadap prestasi belajar fisika, (4) interaksi antara pembelajaran TGT melalui teka-teki silang, kartu dan kemampuan verbal siswa terhadap prestasi belajar fisika, (5) interaksi antara pembelajaran TGT melalui teka-teki silang, kartu dan gaya belajar siswa terhadap prestasi belajar fisika, (6) interaksi antara kemampuan verbal dan gaya belajar siswa terhadap prestasi belajar fisika, (7) interaksi antara pembelajaran TGT, kemampuan verbal dan gaya belajar terhadap prestasi belajar fisika.

\section{Metode Penelitian}

Penelitian dilaksanakan di SMA Batik 1 Surakarta Tahun Pelajaran 2011/2012 yang beralamat di Jln. Slamet Riyadi No. 445 Kecamatan Laweyan, Kota Surakarta, Provinsi Jawa Tengah. Adapun waktu pelaksanaan penelitian ini mulai dari penyusunan proposal hingga pembuatan laporan penelitian dimulai bulan September tahun 2011 sampai dengan tahun Nopember 2012. Penelitian ini adalah penelitian kuasi eksperimen. Kelompok eksperimen I belajar dengan TGT menggunakan media teka teki silang dan kelompok eksperimen II dengan TGT menggunakan media kartu.

Rancangan penelitian dalam penelitian ini disusun sesuai dengan variabel-variabel yang terlibat. Variabel- 
ISSN: 2252-7893, Vol 2, No 12013 (hal 66-75)

http://jurnal.fkip.uns.ac.id/index.php/sains

variabel terlibat dalam penelitian ini merupakan cerminan dari data-data yang akan diperoleh setelah perlakuan terhadap sampel penelitian yang dilakukan. Data yang diperoleh kemudian dianalisis menggunakan uji manova. Teknik pengambilan sampel menggunakan teknik cluster random sampling. Sampel yang digunakan dalam penelitian ini ada 2 kelas, yaitu kelas XII IPA 1 sebagai kelas eksperimen pertama diberi perlakuan menggunakan TGT melalui media teka teki silang dan kelas XII IPA 2 sebagai kelas eksperimen kedua menggunakan TGT melalui media kartu.

Teknik pengumpulan data dalam penelitian ini menggunakan: (1) metode Tes untuk mengetahui prestasi belajar siswa dalam ranah kognitif dan juga untuk mengetahui kemampuan verbal siswa; (2) metode angket digunakan untuk mengetahui gaya belajar dan prestasi afektif siswa; (3) metode observasi dilakukan untuk mendapatkan kumpulan data dari aktivitas belajar siswa pada saat melakukan kegiatan turnamen dan untuk pengamatan perilaku penilaian prestasi belajar ranah afektif.

Instrumen pelaksanaan penelitian dalam penelitian ini berupa silabus, Rencana Pelaksanaan Pembelajaran (RPP) dan Lembar Kerja Siswa (LKS). Instrumen pengambilan data digunakan tes, angket dan observasi. Tes digunakan untuk mengukur prestasi belajar kognitif siswa dan mengukur kemampuan verbal siswa. Angket digunakan untuk mengukur gaya belajar dan prestasi belajar ranah afektif. Observasi untuk mengukur penilaian prestasi belajar ranah afektif.

Uji normalitas data menggunakan

uji Kolmogorov-Smirnov dan uji homogenitas menggunakan Levene's test yang terdapat pada software SPSS 18. Pengujian hipotesis pada penelitian ini menggunakan uji parametrik. Uji parametrik yang digunakan adalah anava tiga jalan dengan General Linier Model $(G L M)$ dan melalui program SPSS versi 18. Uji lanjut anava yang digunakan adalah metode Scheffe.

\section{Hasil Penelitian Dan Pembahasan}

Deskripsi data kemampuan verbal siswa untuk kedua kelas eksperimen tersebut dapat dilihat pada Tabel 1

Tabel 1. Deskripsi Data Prestasi Belajar Ditinjau Dari Kemampuan Verbal Siswa

\begin{tabular}{|c|c|c|c|c|c|}
\hline & \multirow{2}{*}{$\begin{array}{c}\text { Kelompo } \\
\text { kSiswa }\end{array}$} & \multicolumn{2}{|c|}{$\begin{array}{c}\text { Jumlah } \\
\text { Siswa }\end{array}$} & \multirow{2}{*}{$\begin{array}{c}\text { Rata- } \\
\text { rata }\end{array}$} & \multirow{2}{*}{ SD } \\
\hline & & TTS & Kartu & & \\
\hline \multirow{2}{*}{ Kognitif } & $\begin{array}{l}\text { K. Verbal } \\
\text { Tinggi }\end{array}$ & 20 & 24 & 84.02 & 8.33 \\
\hline & $\begin{array}{l}\text { K. Verbal } \\
\text { Rendah }\end{array}$ & 18 & 14 & 74.59 & 9.34 \\
\hline \multirow{2}{*}{ Afektif } & $\begin{array}{l}\text { K. Verbal } \\
\text { Tinggi }\end{array}$ & 20 & 24 & 80.55 & 7.54 \\
\hline & $\begin{array}{l}\text { K. Verbal } \\
\text { Rendah }\end{array}$ & 18 & 14 & 74.19 & 7.85 \\
\hline
\end{tabular}

Pada Tabel 1 diperlihatkan nilai rata-rata prestasi belajar kognitif dan afektif siswa dengan kemampuan verbal tinggi lebih tinggi dan memiliki standar deviasi yang lebih kecil dibandingkan siswa dengan kemampuan verbal rendah. Dengan standar deviasi yang kecil pada kemampuan verbal tinggi menunjukkan bahwa data mengumpul. Data mengumpul menunjukkan data nilai siswa yang baik untuk prestasi belajar kognitif, dan afektif dengan kemampuan verbal tinggi. Sedangkan standar deviasi yang besar pada kemampuan verbal rendah menunjukkan data menyebar. Jadi, siswa yang memiliki kemampuan verbal tinggi menunjukkan nilai siswa lebih baik daripada siswa yang memiliki kemampuan verbal rendah.

Tabel 2. Deskripsi Data Prestasi Belajar Ditinjau Dari Gaya Belajar Siswa

\begin{tabular}{ccccccc} 
& \multirow{2}{*}{$\begin{array}{c}\text { Kelompok } \\
\text { Siswa }\end{array}$} & \multicolumn{3}{c}{$\begin{array}{c}\text { Jumlah } \\
\text { Siswa }\end{array}$} & $\begin{array}{c}\text { Rata- } \\
\text { rata }\end{array}$ & SD \\
\cline { 3 - 6 } KTS & Kartu & Tisual & 21 & 18 & 82.61 & 10.48 \\
\hline \multirow{2}{*}{ Kognitif } & GB Kinestetik & 17 & 20 & 77.35 & 8.54 \\
\cline { 2 - 6 } Afektif & GB Visual & 21 & 18 & 79.13 & 8.10 \\
\cline { 2 - 6 } & GB Kinestetik & 17 & 20 & 76.54 & 8.30 \\
\hline
\end{tabular}

Pada Tabel 2 diperlihatkan nilai rata-rata prestasi belajar kognitif dan afektif siswa dengan gaya belajar visual 
ISSN: 2252-7893, Vol 2, No 12013 (hal 66-75)

http://jurnal.fkip.uns.ac.id/index.php/sains

lebih tinggi dibandingkan siswa dengan gaya belajar kinestetik. Data menunjukkan bahwa nilai siswa yang baik untuk prestasi belajar kognitif dan afektif dengan gaya belajar visual. Jadi, siswa yang memiliki gaya belajar visual menunjukkan nilai siswa lebih baik daripada siswa dengan gaya belajar kinestetik.

Tabel 3. Deskripsi Data Prestasi Belajar Ditinjau

Dari Media Pembelajaran

\begin{tabular}{|c|c|c|c|c|}
\hline & $\begin{array}{c}\text { Kelompok } \\
\text { Siswa }\end{array}$ & $\begin{array}{c}\text { Jumlah } \\
\text { Siswa }\end{array}$ & $\begin{array}{c}\text { Rata- } \\
\text { rata }\end{array}$ & SD \\
\hline \multirow{2}{*}{ Kognitif } & $\begin{array}{l}\text { Teka Teki } \\
\text { Silang }\end{array}$ & 38 & 81.66 & 10.15 \\
\hline & Kartu & 38 & 78.45 & 9.48 \\
\hline \multirow{2}{*}{ Afektif } & $\begin{array}{l}\text { Teka Teki } \\
\text { Silang } \\
\end{array}$ & 38 & 79.10 & 7.31 \\
\hline & Kartu & 38 & 76.63 & 9.02 \\
\hline
\end{tabular}

Pada Tabel 3 diperlihatkan nilai rata-rata prestasi belajar kognitif dan afektif kelas yang belajar dengan media teka teki silang lebih tinggi dibandingkan kelas yang belajar dengan media kartu. Data menunjukkan bahwa nilai siswa yang tinggi untuk prestasi belajar kognitif maupun afektif pada saat pembelajaran menggunakan media teka teki silang. Jadi pembelajaran menggunakan media teka teki silang menunjukkan nilai siswa lebih baik daripada menggunakan media kartu.

Setelah dilakukan uji hipotesis menggunakan manova, baik prestasi belajar kognitif maupun afektif dapat dirangkum dalam uji hipotesis penelitian prestasi belajar. Rangkuman uji hipotesis penelitian prestasi belajar dapat dilihat pada Tabel 4 berikut ini.

Tabel 4. Rangkuman Uji Hipotesis Penelitian Prestasi Belajar

\begin{tabular}{lcccc} 
& \multicolumn{3}{c}{ Penelitian Prestasi Belajar } \\
\cline { 2 - 5 } $\begin{array}{l}\text { Hipotesis } \\
\text { dengan }\end{array}$ & \multicolumn{2}{c}{ Kognitif } & \multicolumn{2}{c}{ Afektif } \\
ANAVA & Sig. & Keputusan & Sig. & Keputusan \\
\hline Media & 0.040 & Ho ditolak & 0.070 & Ho diterima \\
\hline $\begin{array}{l}\text { Kemampuan } \\
\text { Verbal }\end{array}$ & 0.000 & Ho ditolak & 0.000 & Ho ditolak \\
\hline Gaya Belajar & 0.057 & Ho diterima & 0.387 & Ho diterima \\
\hline $\begin{array}{l}\text { Media } * \\
\begin{array}{l}\text { Kemampuan } \\
\text { Verbal }\end{array}\end{array}$ & 0.387 & Ho diterima & 0.379 & Ho diterima \\
\hline
\end{tabular}

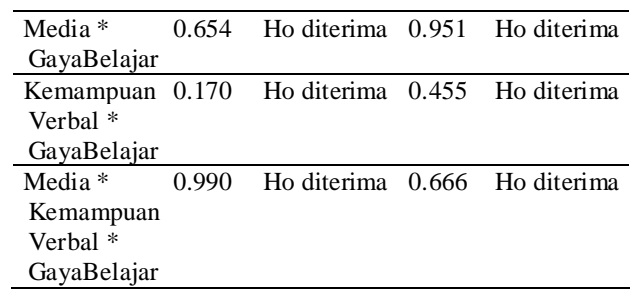

Berdasarkan Tabel 4 dan kriteria pengujian hipotesis pada uraian di atas, maka kesimpulan dari pengujian hipotesis dalam penelitian ini adalah sebagai berikut.

\section{Pengaruh pembelajaran TGT menggunakan teka teki silang dan kartu terhadap prestasi belajar.}

Pada penelitian ini, berdasarkan hasil pengujian hipotesis secara statistik dinyatakan bahwa untuk prestasi belajar kognitif signifikansi sebesar 0,040 (signifikansi < 0,05), maka $\mathrm{H}_{0}$ ditolak dan $\mathrm{H}_{1}$ diterima. Hal ini berarti ada pengaruh pembelajaran fisika menggunakan TGT melalui teka teki silang dan kartu terhadap prestasi belajar kognitif siswa. Untuk prestasi belajar afektif signifikansi sebesar 0,070 (signifikansi > 0,05), maka $\mathrm{H}_{0}$ diterima dan $\mathrm{H}_{1}$ ditolak. Hal ini berarti untuk prestasi belajar afektif secara statistik dinyatakan tidak ada pengaruh pembelajaran fisika menggunakan TGT melalui teka teki silang dan kartu terhadap prestasi belajar afektif siswa. Hal ini disebabkan media teka teki silang dan kartu yang digunakan berisi latihan soal, dan materi pelajaran yang sebagian besar memberikan informasi yang mendukung kemampuan kognitif siswa dalam memahami materi Fisika Atom.

Rerata kelas eksperimen I yang diberi perlakuan pembelajaran dengan media teka teki silang adalah 81.66 sedangkan rerata kelas eksperimen II yang diberi perlakuan pembelajaran dengan media kartu adalah 78.45. Dengan demikian, maka dapat disimpulkan bahwa pembelajaran menggunakan TGT melalui teka teki silang menghasilkan prestasi belajar kognitif yang lebih baik daripada pembelajaran menggunakan TGT melalui kartu pada materi Fisika Atom. Walaupun 
ISSN: 2252-7893, Vol 2, No 12013 (hal 66-75)

http://jurnal.fkip.uns.ac.id/index.php/sains

secara statistik tidak ada pengaruh terhadap prestasi belajar afektif, namun demikian rerata kelas eksperimen I untuk prestasi belajar afektif sebesar 79,10 lebih tinggi dari kelas eksperimen II yang memiliki rerata prestasi belajar afektif sebesar 76,63.

\section{Pengaruh kemampuan verbal terhadap prestasi belajar.}

Pada penelitian ini, berdasarkan hasil pengujian hipotesis secara statistik dinyatakan bahwa untuk prestasi belajar kognitif, dan afektif, mempunyai signifikansi yang sama yaitu 0,000 (signifikansi < 0,05), maka baik untuk prestasi belajar kognitif,maupun afektif, $\mathrm{H}_{0}$ ditolak dan $\mathrm{H}_{1}$ diterima. Hal ini berarti ada pengaruh kemampuan verbal siswa terhadap prestasi belajar siswa baik untuk prestasi belajar kognitif, maupun afektif. Hal ini sejalan dengan penelitian dari Muh. Miftah (2010) tentang "Keefektifan model pembelajaran langsung dan pembelajaran kooperatif pada materi pokok himpunan kelas VII ditinjau dari kemampuan verbal siswa". Pada penelitian tersebut dihasilkan bahwa terdapat pengaruh yang signifikan antara siswa dengan kategori kemampuan verbal tinggi, sedang, dan rendah terhadap prestasi belajar Matematika.

Rerata prestasi belajar kognitif dan afektif siswa yang berkemampuan verbal tinggi secara berturut-turut adalah 84,02 dan 80,55 sedangkan rerata prestasi belajar kognitif,dan afektif siswa yang berkemampuan verbal rendah secara berturut-turut adalah 74,59 dan 74,19. Dengan demikian, maka dapat disimpulkan bahwa siswa yang mempunyai kemampuan verbal tinggi memperoleh prestasi belajar baik prestasi belajar kognitif, maupun afektif yang lebih baik dibandingkan dengan siswa yang mempunyai kemampuan rendah. Dengan kata lain, semakin tinggi kemampuan verbal siswa maka makin tinggi pula prestasi belajar yang dicapai, sebaliknya semakin rendah kemampuan verbal siswa maka makin rendah pula prestasi belajar yang dicapainya.
Hal ini dikarenakan, dengan kemampuan verbal yang baik, siswa dapat mengkomunikasikan pengetahuan, ide, gagasan, pendapat, pikiran, pengalaman, dan kecakapan yang dimiliki baik secara lisan maupun tulisan. Sebagai contoh, secara lisan siswa dapat mengkomunikasikan pengetahuan, pendapat, dan pemikiran melalui kegiatan diskusi, bertanya kepada guru atau teman serta menjawab pertanyaan guru atau teman secara lisan. Melalui tulisan siswa dapat mengerjakan soal-soal yang diberikan guru, dengan kemampuan verbal yang dimiliki.

\section{Pengaruh gaya belajar terhadap prestasi belajar.}

Pada penelitian ini, berdasarkan hasil pengujian hipotesis secara statistik dinyatakan bahwa untuk prestasi belajar kognitif, dan afektif, mempunyai signifikansi secara berturut-turut yaitu 0,057 dan 0,387 (signifikansi > 0,05), maka $\mathrm{H}_{0}$ diterima dan $\mathrm{H}_{1}$ ditolak. Hal ini berarti tidak ada pengaruh gaya belajar siswa terhadap prestasi belajar siswa baik prestasi belajar kognitif maupun afektif siswa. Hasil penelitian ini tidak sejalan dengan penelitian yang dilakukan Eko Sutrisno (2010) tentang "pembelajaran fisika menggunakan group investigation dan jigsaw ditinjau dari gaya belajar dan aktivitas belajar siswa". Pada penelitian tersebut diketahui bahwa ada pengaruh gaya belajar terhadap prestasi belajar fisika. Perbedaan ini karena gaya belajar siswa diketahui dari angket yang diisi siswa sehingga dapat dimungkinkan adanya ketidakkonsistenan siswa dalam menjawab angket tersebut atau dimungkinkan siswa mengisi dengan tidak jujur. Selain itu pembatasan gaya belajar pada penelitihan dibatasi gaya belajar visual dan kinestetik, padahal ada gaya belajar yang lain yaitu audiotorial. Hal ini dapat mengakibatkan hasil angket tidak sesuai dengan gaya belajar yang sebenarnya dimiliki siswa.

Selain itu, keberhasilan kegiatan belajar mengajar di sekolah dipengaruhi 
ISSN: 2252-7893, Vol 2, No 12013 (hal 66-75)

http://jurnal.fkip.uns.ac.id/index.php/sains

oleh beberapa faktor baik faktor internal maupun faktor eksternal. Faktor internal adalah faktor yang berasal dari dalam diri siswa, misalnya: minat, perhatian, kebiasaan, usaha, motivasi belajar, kemampuan berpikir, kemampuan analisis, kemampuan menggunakan alat ukur, kemampuan verbal, sikap ilmiah, dan gaya belajar siswa. Sedangkan faktor eksternal adalah faktor yang berasal dari luar diri siswa. Berasal dari lingkungan sekitar, baik lingkungan keluarga, sekolah, maupun masyarakat. Menurut Nana Sudjana (1996: 6): "Faktor yang mempengaruhi keberhasilan kegiatan belajar-mengajar di lingkungan sekolah antara lain guru, sarana belajar, kurikulum, teman sekelas, disiplin, dan sebagainya". Kutipan tersebut menjelaskan bahwa guru, fasilitas belajar, kurikulum, teman sekelas, dan sikap disiplin siswa mempengaruhi keberhasilan kegiatan belajar mengajar di sekolah. Dari uraian di atas diduga bahwa gaya belajar bukan satu-satunya faktor yang menentukan prestasi belajar siswa.

\section{Interaksi antara pembelajaran TGT dengan kemampuan verbal terhadap prestasi belajar. \\ Pada penelitian ini, berdasarkan} hasil pengujian hipotesis secara statistik dinyatakan bahwa untuk prestasi belajar kognitif signifikansi adalah 0,387 (signifikansi > 0,05) dan prestasi belajar afektif signifikansi adalah 0,379 (signifikansi > 0,05), maka $\mathrm{H}_{0}$ diterima dan $\mathrm{H}_{1}$ ditolak. Hal ini berarti untuk prestasi belajar kognitif dan afektif secara statistik dinyatakan tidak ada interaksi antara pembelajaran fisika menggunakan teams games tournament melalui teka teki silang dan kartu dan kemampuan verbal siswa terhadap prestasi belajar siswa baik prestasi belajar kognitif maupun afektif.

Pada prestasi belajar kognitif dan afektif, tidak ditemukan pengaruh bersama yang signifikan antara media pembelajaran dengan kemampuan verbal siswa terhadap prestasi belajar kognitif dan afektif siswa. Pengaruh yang diberikan media teka teki silang dan kartu terhadap prestasi belajar kognitif dan afektif siswa merupakan pengaruh yang berdiri sendiri dan tidak berhubungan dengan kemampuan verbal siswa. Begitu pula sebaliknya, pengaruh yang diberikan kemampuan verbal siswa terhadap prestasi belajar kognitif dan afektif merupakan pengaruh yang berdiri sendiri dan tidak berhubungan dengan media teka teki silang dan kartu.

Pada prestasi belajar kognitif dan afektif, dua variabel bebas tersebut yaitu media pembelajaran dan kemampuan verbal tidak menghasilkan kombinasi efek yang signifikan. Oleh karena itu dapat disimpulkan tidak ada interaksi antara pembelajaran fisika menggunakan TGT melalui teka teki silang dan kartu dan kemampuan verbal siswa terhadap prestasi belajar siswa baik prestasi belajar kognitif maupun afektif siswa.

\section{Interaksi pembelajaran TGT dengan gaya belajar terhadap prestasi belajar.}

Pada penelitian ini, berdasarkan hasil pengujian hipotesis secara statistik dinyatakan bahwa untuk prestasi belajar kognitif, dan afektif, mempunyai signifikansi secara berturut-turut yaitu 0,654 dan 0,951 (signifikansi > 0,05), maka $\mathrm{H}_{0}$ diterima dan $\mathrm{H}_{1}$ ditolak. Hal ini berarti tidak ada interaksi antara pembelajaran fisika menggunakan TGT melalui teka teki silang dan kartu dan gaya belajar siswa terhadap prestasi belajar siswa baik prestasi belajar kognitif maupun afektif siswa.

Pada prestasi belajar kognitif maupun afektif, tidak ditemukan pengaruh bersama yang signifikan antara media pembelajaran dengan gaya belajar siswa terhadap prestasi belajar kognitif maupun afektif siswa. Pengaruh yang diberikan media teka teki silang dan kartu terhadap prestasi belajar kognitif dan afektif siswa merupakan pengaruh yang berdiri sendiri dan tidak berhubungan dengan gaya belajar siswa. Begitu pula sebaliknya, pengaruh yang diberikan gaya belajar siswa terhadap prestasi belajar kognitif dan afektif merupakan pengaruh yang berdiri sendiri dan tidak 
ISSN: 2252-7893, Vol 2, No 12013 (hal 66-75)

http://jurnal.fkip.uns.ac.id/index.php/sains

berhubungan dengan media teka teki silang dan kartu.

Pada prestasi belajar kognitif dan afektif, dua variabel bebas tersebut yaitu media pembelajaran dan gaya belajar tidak menghasilkan kombinasi efek yang signifikan. Oleh karena itu dapat disimpulkan tidak ada interaksi antara pembelajaran fisika menggunakan TGT melalui teka teki silang dan kartu dan gaya belajar siswa terhadap prestasi belajar siswa baik prestasi belajar kognitif maupun afektif siswa.

\section{Interaksi antara kemampuan verbal dengan gaya belajar terhadap prestasi belajar.}

Pada penelitian ini, berdasarkan hasil pengujian hipotesis secara statistik dinyatakan bahwa untuk prestasi belajar kognitif signifikansi sebesar 0,170 (signifikansi < 0,05) dan prestasi belajar afektif signifikansi sebesar 0,455 (signifikansi $<0,05$ ), maka $\mathrm{H}_{0}$ diterima dan $\mathrm{H}_{1}$ ditolak. Hal ini berarti tidak ada interaksi antara kemampuan verbal dan gaya belajar siswa terhadap prestasi belajar siswa baik prestasi belajar kognitif maupun afektif siswa.

Dalam penelitian ini untuk prestasi belajar kognitif maupun efektif tidak ditemukan pengaruh bersama yang signifikan antara kemampuan verbal dan gaya belajar siswa. Pengaruh yang diberikan kemampuan verbal siswa terhadap prestasi belajar kognitif dan afektif siswa merupakan pengaruh yang berdiri sendiri dan tidak berhubungan dengan gaya belajar siswa. Oleh karena itu dapat disimpulkan tidak ada interaksi antara kemampuan verbal dan gaya belajar terhadap prestasi belajar kognitif maupun afektif siswa.

\section{Interaksi antara pembelajaran TGT,} kemampuan verbal, gaya belajar terhadap prestasi belajar .

Pada penelitian ini, berdasarkan hasil pengujian hipotesis secara statistik dinyatakan bahwa untuk prestasi belajar kognitif signifikansi sebesar $\quad 0,990$ (signifikansi > 0,05) dan prestasi belajar afektif signifikansi sebesar 0,666 (signifikansi > 0,05), maka $\mathrm{H}_{0}$ diterima dan $\mathrm{H}_{1}$ ditolak. Hal ini berarti tidak ada interaksi antara pembelajaran fisika menggunakan teams games tournament melalui teka teki silang dan kartu, kemampuan verbal, dan gaya belajar siswa terhadap prestasi belajar siswa baik prestasi belajar kognitif maupun afektif siswa.

Pada prestasi belajar kognitif dan afektif, tidak ditemukan pengaruh bersama yang signifikan antara media, kemampuan verbal, dan gaya belajar siswa terhadap prestasi belajar kognitif dan afektif. Siswa yang diberi pembelajaran menggunakan media teka teki silang memiliki rata-rata yang lebih baik daripada siswa yang diberi pembelajaran menggunakan media kartu, siswa dengan kemampuan verbal tinggi memiliki rata-rata lebih baik daripada siswa dengan kemampuan verbal rendah, siswa dengan gaya belajar yang tepat memiliki rata-rata lebih baik. Hal tersebut karena keberhasilan belajar mengajar dipengaruhi oleh beberapa faktor, baik faktor internal maupun faktor eksternal siswa. Faktor-faktor tersebut tidak sepenuhnya dapat diperhatikan dan dikontrol oleh guru. Selain itu siswa tidak hanya belajar di sekolah saja tetapi dapat juga belajar di luar sekolah.

\section{Kesimpulan Dan Rekomendasi}

Hasil penelitian ini dapat disimpulkan sebagai berikut:

1. Ada pengaruh pembelajaran fisika menggunakan teams games tournament melalui teka teki silang dan kartu terhadap prestasi belajar siswa pada aspek kognitif, namun tidak ada pengaruh pada aspek afektif.

2. Ada pengaruh kemampuan verbal tinggi dengan rendah terhadap prestasi belajar siswa pada aspek kognitif maupun afektif.

3. Tidak ada pengaruh gaya belajar visual, maupun kinestetik terhadap prestasi belajar siswa pada aspek kognitif dan afektif. 
ISSN: 2252-7893, Vol 2, No 12013 (hal 66-75)

http://jurnal.fkip.uns.ac.id/index.php/sains

4. Tidak ada interaksi antara pembelajaran fisika menggunakan teams games tournament melalui teka teki silang dan kartu dengan kemampuan verbal siswa terhadap prestasi belajar siswa pada aspek kognitif maupun pada aspek afektif.

5.Tidak ada interaksi antara pembelajaran fisika menggunakan teams games tournament melalui teka teki silang dan kartu dengan gaya belajar siswa terhadap prestasi belajar siswa pada aspek kognitif maupun afektif.

6. Tidak ada interaksi antara kemampuan verbal dengan gaya belajar siswa terhadap prestasi belajar siswa pada aspek kognitif maupun afektif.

7.Tidak ada interaksi antara pembelajaran fisika menggunakan teams games tournamens melalui teka teki silang dan kartu, kemampuan verbal, gaya belajar terhadap prestasi belajar siswa pada aspek kognitif maupun aspek afektif.

Hasil penelitian ini memberikan gambaran yang jelas tentang penerapan pembelajaran fisika menggunakan teams games tournament melalui teka teki silang dan kartu ditinjau dari kemampuan verbal dan gaya belajar siswa pada materi Fisika Atom.

Rekomendasi yang dapat dikemukakan berdasarkan kesimpulan penelitian ini antara lain:

a.Dalam skenario pembelajaran guru sebaiknya memperhatikan gaya belajar siswa karena setiap siswa memiliki gaya belajar yang berbeda-beda diantaranya gaya belajar terbagi atas: auditorial, visual dan kinestetik.

b.Guru sebaiknya menggunakan teams games tournament melalui teka teki silang dalam melaksanakan pembelajaran fisika khususnya pada materi Fisika Atom, dalam hal ini guru sebagai fasilitator dan siswa secara aktif terlibat dalam proses belajar mandiri.

c. Dalam pembelajaran menggunakan media, guru sebaiknya mempersiapkan strategi dan perlengkapan yang diperlukan, agar proses pembelajaran dapat berlangsung dengan lancar dan sesuai dengan tujuan yang diharapkan.

\section{Daftar Pustaka}

Eko Sutrisno. (2010). PembelajaranFisika model Group Investigation (GI) dan Jigsaw ditinjau dari Gaya Belajar dan Aktivitas Belajar Siswa.Tesis

Muh. Miftah. (2010). Keefektifan Model

Pembelajaran Langsung dan Pembelajaran Kooperatif pada Materi Pokok Himpunan Kelas VII Ditinjau dari Kemampuan Verbal Siswa. Tesis.

Nana Sudjana. (2009). Dasar-dasar Proses Belajar Mengajar. Bandung : Sinar Baru Algresindo.

Slavin, Robert E. (2008). Cooperative Learning. Teori, Riset dan Praktek.Terjemah Nurulita. Bandung: Nusa Media. 